\title{
The Impact of Dementia on the Clinical Outcome of COVID-19: A Systematic Review and Meta-Analysis
}

\author{
Nanyang Liu ${ }^{\mathrm{a}}$, Jiahui Sun ${ }^{\mathrm{b}}$, Xiyuan Wang ${ }^{\mathrm{b}}$, Ming Zhao ${ }^{\mathrm{b}}$, Qianqian Huang ${ }^{\mathrm{b}}$ and Hao Li ${ }^{\mathrm{a}, *}$ \\ ${ }^{a}$ Department of Geratology, Xiyuan Hospital, China Academy of Chinese Medical Sciences, Beijing, China \\ ${ }^{\mathrm{b}}$ Graduate School, Beijing University of Chinese Medicine, Beijing, China
}

Accepted 21 October 2020

\begin{abstract}
.
Background: The emergence of the coronavirus disease 2019 (COVID-19) has brought large challenges to dementia patients. We reviewed the existing literature on COVID-19 to assess the incidence and mortality of dementia comorbidities in COVID19 patients.

Objective: To investigate the impact of pre-existing dementia comorbidities on COVID-19.

Methods: We searched the PubMed, Embase, and Web of Science databases for patients with preexisting dementia who were diagnosed with COVID-19. The statistical data on the prevalence and mortality of dementia comorbidities were examined. A fixed-or random-effect model was used to calculate the overall pooled risk estimates. Forest plots were generated to show the summarized results.

Results: A total of 265 articles were retrieved from the three databases. After removing duplicates and performing two screenings, 10 articles were selected for meta-analysis, including 119,218 participants. Overall, the meta-analysis of the 10 studies showed that the incidence of dementia in COVID-19 patients was (R: 9\%, [95\% CI: 6\% to 13\%]). Moreover, the meta-analysis of 9 studies showed that the mortality rate of individuals with dementia after being infected with COVID-19 was higher than that of individuals with no dementia (OR: 5.17 [95\% CI: 2.31 to 11.59]). Substantial heterogeneity was observed in this meta-analysis. Significant publication bias was also found.

Conclusion: Emerging literature shows that dementia comorbidities are a high risk factor for the prevalence and mortality of COVID-19. Our results should have an impact on preventive interventions and encourage more targeted approaches to prioritize older people with specific risk factors, such as dementia.
\end{abstract}

Keywords: Alzheimer's disease, coronavirus disease 2019, dementia, meta-analysis

\section{INTRODUCTION}

Since the first case was detected in Wuhan, China in December 2019, a novel type of coronavirus named coronavirus disease 2019 (COVID-19) caused by severe acute respiratory syndrome coronavirus2 (SARS-CoV-2) has become a global pandemic threat [1]. As of August 2020, it has caused more

\footnotetext{
${ }^{*}$ Correspondence to: Hao Li, Department of Geratology, Xiyuan Hospital, China Academy of Chinese Medical Sciences, Beijing 10091, China. Tel.: (+86) 106283 5631; Fax: (+86) 10 6283 5631; E-mail: xyhplihao1965@126.com.
}

than 20 million infections and more than 750,000 deaths in 216 countries and territories [2]. The clinical outcomes of COVID-19 range from potentially asymptomatic patients to severe progressive pneumonia or acute respiratory distress syndrome leading to death [3]. The disease is especially serious in the elderly and people with chronic diseases [4]. Understanding these differences is essential to protect vulnerable groups and guide effective policies and treatments.

In the past few decades, the prevalence of dementia worldwide has risen sharply. With the increasing 
aging of the global population, over 50 million people are living with dementia, and this number is set to increase to 152 million by 2050 [5]. Due to aging, weakness, poor autonomy, chronic immune disorders [6], and other chronic diseases, especially comorbidities of vascular diseases [7], people with dementia have become the most vulnerable population. Epidemiological evidence shows that patients with dementia are vulnerable to infectious diseases, such as respiratory syncytial virus disease, severe acute respiratory syndrome coronavirus, and influenza A [8]. Their clinical outcome after infection is worse than that of the general population $[9,10]$. During the COVID-19 pandemic, patients with dementia have borne a greater burden than the rest of the population $[11,12]$. Due to the increase in morbidity and mortality, the pandemic has exacerbated these patients' vulnerability. Lockdowns and social distancing measures have made their social support and medical systems unavailable [13]. Recent observational data reported that the prevalence of dementia is high among elderly patients hospitalized with COVID-19 [14]. Another study using available data on dementia and COVID-19 in 185 countries found a significant correlation between the burden of dementia and COVID-19 cases [8]. Additionally, patients with dementia have a higher mortality rate from COVID-19. A retrospective cohort study showed that the mortality rate of dementia patients was higher than that of patients with other mental illnesses [15]. However, research based on small samples is insufficient to confirm that pre-existing dementia may be more susceptible to COVID-19 and poor prognosis. Therefore, we conducted a comprehensive review of the existing literature on COVID-19 to assess the prevalence and mortality of patients with dementia following a COVID-19 diagnosis to provide evidence for clinical decision-making.

\section{METHODS}

This systematic review and meta-analysis were conducted according to the Preferred Reporting Item for Systematic Review and Meta-analysis Protocol (PRISMA) [16].

\section{Data sources and search strategy}

Two independent reviewers searched the PubMed, Embase, and Web of Science databases from the date of inception to August 1, 2020. The search terms included Alzheimer's disease, dementia, COVID-19, and SARS-CoV-2, which were appropriately adjusted for the different databases. The Google search engine was used to search for grey literature and a manual review of the listed references was used to find relevant articles. The included research was not restricted by design and must have been available in English. Due to the rapid development of the pandemic, COVID19 articles that were not peer-reviewed through pre-acceptance open access were included.

\section{Eligibility criteria}

Inclusion criteria: 1 ) adult patients (age $\geq 18$ years old); 2) confirmed or received hospitalization for COVID-19; 3) report data on pre-existing dementia comorbidities in the course of the disease. Exclusion criteria: 1) results that cannot be pooled through calculation; 2) case reports, case series, duplicate reports, in vitro, and animal studies; 3 ) the full text of the study was not available; 4) not relevant to the subject of the study.

\section{Study selection}

All of the retrieved articles were independently identified by two reviewers. After removing duplicates, the two reviewers read the title and abstract of the articles to check for the eligibility criteria to check them. Articles that meet the standards were obtained in full text for reading, and the controversial documents were eliminated by discussions between the two reviewers. A third reviewer assisted if they were unable to reach an agreement.

\section{Data extraction and quality assessment}

Two independent reviewers used a predesigned form to extract data from the eligible studies. The form included the following items: general information (e.g., publication year and country), participant characteristics (e.g., age, gender, and race), study characteristics (e.g., sample size and study design), exposure factor (COVID-19 infection), and outcomes (prevalence and mortality of dementia in the context of COVID-19). Disagreements were resolved by consensus or by consulting with the third reviewer. The Newcastle-Ottawa Scale (NOS) recommended by the Cochrane Collaboration was used to assess the methodological quality of the included studies [17]. Two researchers conducted quality assessments and resolved any differences between the two authors through discussion or consensus. 


\section{Statistical analysis}

Stata software (version 14.0) was used for statistical analysis. The incidence rate $(\mathrm{R})$ was used to measure the dementia comorbidity of COVID-19, while the pooled OR value was used to measure mortality. Heterogeneity between the included studies was assessed by the $I^{2}$ statistic and $p$ values. $I^{2} \leq 50 \%$ was considered to have little heterogeneity; $I^{2}>50 \%$ was considered to have substantial heterogeneity [18]. The random-or fixed-effect model was conducted to assess the data, but only the randomeffect analyses were reported when the heterogeneity was significant and could not be explained. Sensitivity analysis was conducted by sequential removal of each trial to assess the impact of individual studies on the overall pooled estimates. Forest plots were generated to prove the pooled results. In addition, a subgroup analysis stratified by participant age and the sample size was performed. Publication bias was assessed by visual inspection of the funnel plot. A value of $p<0.05$ was deemed to be statistically significant.

\section{RESULTS}

\section{Literature search}

We searched 265 related studies from all of the mentioned databases, 24 of which were excluded because they were duplicates. The remaining 241 records were filtered based on titles and abstracts, and 200 were excluded due to unrelated topics. We reviewed the full text of the remaining 41 studies and identified 10 studies that met the inclusion criteria of the meta-analysis, including 5 case-control $[13,15$, 19-21], and 5 cohort studies [14, 22-25]. The detailed search process is shown in Fig. 1.

\section{Study characteristics and quality assessment}

Ten studies involving 119,218 participants contributed to the meta-analysis. Two were conducted in the United States $[19,22], 6$ were conducted in Europe $[13,14,20,21,24,25]$, and 2 were conducted in Asia [15, 23]. Nine of the studies were retrospective [13-15, 19-24]. The sample size ranged from 69 to 109,367, with males accounting for more than $40 \%$. The majority of the participants were over 60 years old. COVID-19 was confirmed by reverse transcription polymerase chain reaction testing on

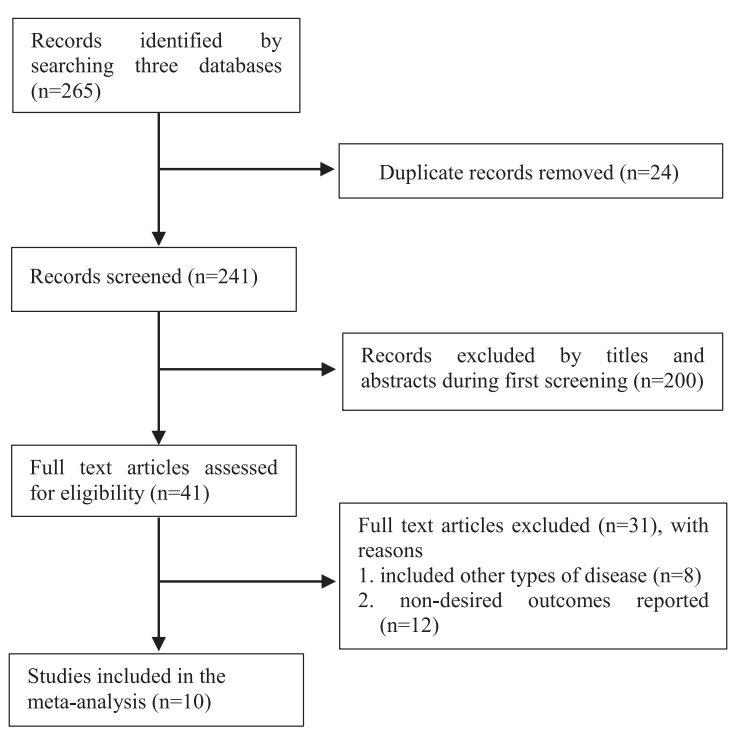

Fig. 1. The process of study selection for the meta-analysis.

nasopharyngeal swabs; however, the diagnosis of dementia was not clearly defined in most of the studies. Of the 10 qualified studies, 6 were considered to have high methodological quality (score $\geq 7$ ), while 4 studies were of medium quality (score 5-6). The scores ranging from 5 to 9 indicated that the included studies were generally high quality. The characteristics of the included studies and details of the patients are shown in Table 1.

\section{Impact of dementia on the prevalence of COVID-19 patients}

Figure 2 shows the results from the random-effects model that pooled the incidence of dementia comorbidities in COVID-19 patients. Ten studies reported the incidence of dementia comorbidities in COVID19 patients, ranging from $3 \%$ to $20 \%$. Overall, the meta-analysis of the 10 studies showed that the incidence of dementia in COVID-19 patients was (R: 9\%, [95\% CI: $6 \%$ to $13 \%$ ]). Substantial heterogeneity was observed across the studies $\left(p=0.000, I^{2}=97.0 \%\right)$. A subgroup analysis based on sample size and age showed no substantial change in heterogeneity. The robustness of the results was evaluated by deleting each study in turn and reanalyzing the data sets, leading to no significant changes in the pooled $\mathrm{R}$ estimate. In addition, significant asymmetry was observed in the funnel plot, which indicates evidence of publication bias (Fig. 3A). 
Table 1

Summary characteristics and quality assessment of studies included in the meta-analysis

\begin{tabular}{|c|c|c|c|c|c|c|c|c|}
\hline $\begin{array}{l}\text { Study } \\
\text { year [ref] }\end{array}$ & Country & Study design & Sample & Age & Sex (male) & $\begin{array}{l}\text { Diagnosis of } \\
\text { COVID }\end{array}$ & Outcomes & NOS \\
\hline $\begin{array}{l}\text { Atkins } \\
2020[14]\end{array}$ & England & cohort study & 507 & $\begin{array}{l}\text { mean age: } \\
74.3 \pm 4.5\end{array}$ & NR & $\begin{array}{l}\text { Confirmed } \\
\text { with RT-PCR }\end{array}$ & $\begin{array}{l}\text { Comorbidities of COVID-19 } \\
\text { death }\end{array}$ & 6 \\
\hline $\begin{array}{l}\text { Bianchetti } \\
2020[13]\end{array}$ & Italy & $\begin{array}{l}\text { case-control } \\
\text { study }\end{array}$ & 627 & $\begin{array}{l}\text { dementia: } \\
82.6 \pm 5.3 \\
\text { non- } \\
\text { dementia: } \\
68.9 \pm 12.7\end{array}$ & $335(53.4 \%)$ & $\begin{array}{l}\text { Confirmed } \\
\text { with RT-PCR }\end{array}$ & $\begin{array}{l}\text { Diagnosis of dementia, } \\
\text { modalities of onset of the } \\
\text { COVID-19 infection, } \\
\text { symptoms of presentation at } \\
\text { the hospital and outcomes } \\
\text { were recorded }\end{array}$ & 8 \\
\hline $\begin{array}{l}\text { Burn } \\
2020[25]\end{array}$ & Spain & cohort study & 109,367 & $\begin{array}{l}\text { median } \\
\text { (IQR): } 47 \\
(36.0,61.0)\end{array}$ & $\begin{array}{l}44,894 \\
(41.0 \%)\end{array}$ & $\begin{array}{l}\text { Confirmed } \\
\text { with RT-PCR }\end{array}$ & $\begin{array}{l}\text { Study outcomes included an } \\
\text { outpatient clinical diagnosis } \\
\text { of COVID-19, a } \\
\text { hospitalization with } \\
\text { COVID-19, and death }\end{array}$ & 9 \\
\hline $\begin{array}{l}\text { Covino } \\
2020[22]\end{array}$ & Italy & $\begin{array}{l}\text { case-control } \\
\text { study }\end{array}$ & 69 & aged $80-98$ y & $37(53.6 \%)$ & $\begin{array}{l}\text { Confirmed } \\
\text { with RT-PCR }\end{array}$ & $\begin{array}{l}\text { The primary study end-point } \\
\text { was the patient's death. } \\
\text { Survival follow up was } \\
\text { assessed at } 30 \text { days from } \\
\text { admission. }\end{array}$ & 7 \\
\hline $\begin{array}{l}\text { van } \\
\text { Gerwen } \\
2020[23]\end{array}$ & $\begin{array}{l}\text { United } \\
\text { States }\end{array}$ & cohort study & 3,703 & $\begin{array}{l}\text { mean age: } \\
56.8 \mathrm{y}\end{array}$ & $\begin{array}{l}2,049 \\
(55.3 \%)\end{array}$ & $\begin{array}{l}\text { Confirmed } \\
\text { with RT-PCR }\end{array}$ & $\begin{array}{l}\text { Hospital admission, need for } \\
\text { invasive mechanical } \\
\text { ventilation (i.e., intubation), } \\
\text { and all-cause mortality. }\end{array}$ & 7 \\
\hline $\begin{array}{l}\text { Hwang } \\
2020[24]\end{array}$ & Korea & cohort study & 103 & $\begin{array}{l}\text { mean age: } \\
67.62 \pm 15.32\end{array}$ & $52(50 \%)$ & $\begin{array}{l}\text { Confirmed } \\
\text { with RT-PCR }\end{array}$ & $\begin{array}{l}\text { Underlying chronic medical } \\
\text { and neurological diseases } \\
\text { were investigated }\end{array}$ & 8 \\
\hline $\begin{array}{l}\text { Miyashita } \\
2020[20]\end{array}$ & $\begin{array}{l}\text { United } \\
\text { States }\end{array}$ & $\begin{array}{l}\text { case-control } \\
\text { study }\end{array}$ & 2,071 & aged $\geq 60 y$ & $\begin{array}{l}1,099 \\
(55.7 \%)\end{array}$ & $\begin{array}{l}\text { Confirmed } \\
\text { with RT-PCR }\end{array}$ & $\begin{array}{l}\text { Primary outcome was } \\
\text { all-cause mortality. } \\
\text { Secondary outcomes } \\
\text { included the need for } \\
\text { hospital admission, } \\
\text { intubation or intensive care } \\
\text { unit admission }\end{array}$ & 6 \\
\hline $\begin{array}{l}\text { De Smet } \\
2020[21]\end{array}$ & Belgium & $\begin{array}{l}\text { case-control } \\
\text { study }\end{array}$ & 88 & aged 65-97 y & $48(59 \%)$ & $\begin{array}{l}\text { Confirmed } \\
\text { with RT-PCR }\end{array}$ & $\begin{array}{l}\text { Frailty and Mortality in } \\
\text { Hospitalized Older Adults } \\
\text { With COVID-19 }\end{array}$ & 5 \\
\hline $\begin{array}{l}\text { Rossi } \\
2020[26]\end{array}$ & Italy & $\begin{array}{l}\text { prospective } \\
\text { cohort study }\end{array}$ & 2,653 & $\begin{array}{l}\text { mean age: } \\
63.2\end{array}$ & $\begin{array}{l}1,328 \\
(50.1 \%)\end{array}$ & $\begin{array}{l}\text { Confirmed } \\
\text { with RT-PCR }\end{array}$ & $\begin{array}{l}\text { The outcomes were } \\
\text { hospitalization and death }\end{array}$ & 5 \\
\hline $\begin{array}{l}\text { Wan } \\
2020[15]\end{array}$ & China & $\begin{array}{l}\text { case-control } \\
\text { study }\end{array}$ & 30 & $\begin{array}{l}\text { severe group: } \\
66.73 \pm 7.30 \\
\text { non-severe } \\
\text { group: } \\
61.47 \pm 14.74\end{array}$ & $10(33.3 \%)$ & $\begin{array}{l}\text { Confirmed } \\
\text { with RT-PCR }\end{array}$ & $\begin{array}{l}\text { The factors affecting the } \\
\text { prognosis of patients with } \\
\text { mental disorders with } \\
\text { COVID-19 }\end{array}$ & 6 \\
\hline
\end{tabular}

RT-PCR, Reverse Transcription Polymerase Chain Reaction; COVID-19, Coronavirus Disease 2019; NR, not report.

\section{Impact of dementia on the mortality of COVID-19 patients}

Figure 4 shows the results from the random-effects model that pooled the ORs for the mortality of dementia comorbidities in patients with COVID-19. Nine studies reported mortality from dementia comorbidities [13, 15, 19-25]. Of the 9 studies, 8 showed that the mortality rate of COVID-19 in the dementia group was higher than that of the non-dementia group. The ORs varied from 1.54 to 17.25 across the studies. Overall, meta-analysis of the 9 studies showed that the mortality rate of individuals with dementia after being infected with COVID-19 was higher than that of individuals with non-dementia (OR: 5.17 [95\% CI: 2.31 to 11.59$])$. Substantial heterogeneity was observed $\left(p=0.000, I^{2}=96.8 \%\right)$. Sensitivity analysis was performed to explore potential sources of heterogeneity between the studies. We investigated the influence of a single study on the overall risk estimate by excluding one study in each turn. Overall, exclusion of the study of Bure et al. resulted in a lower estimate of the overall risk (OR: 3.55 [95\% CI: 2.64 to 4.79]); however, slight heterogeneity was observed 


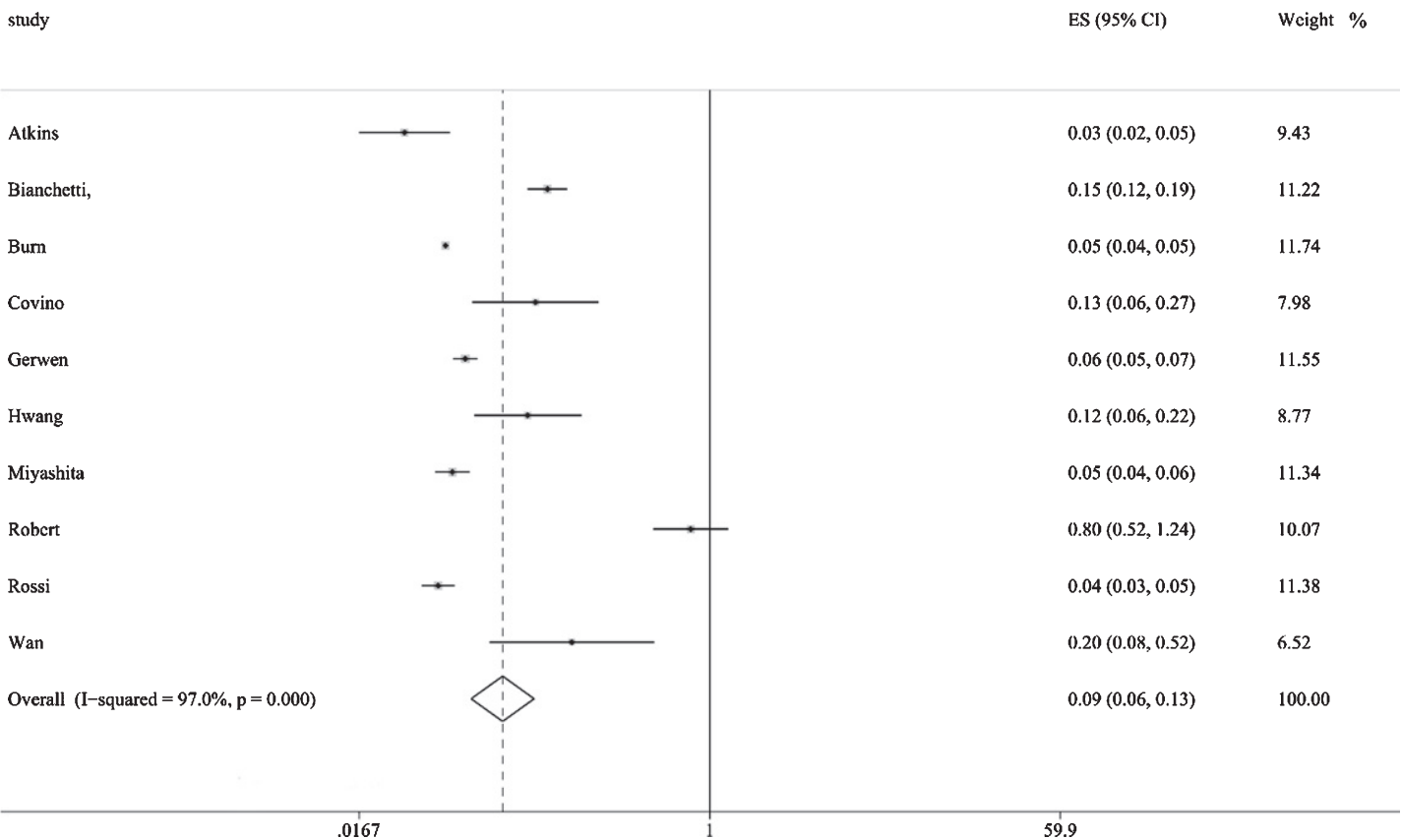

Fig. 2. Results from the random-effects model that pooled the incidence of dementia comorbidities in COVID-19 patients.
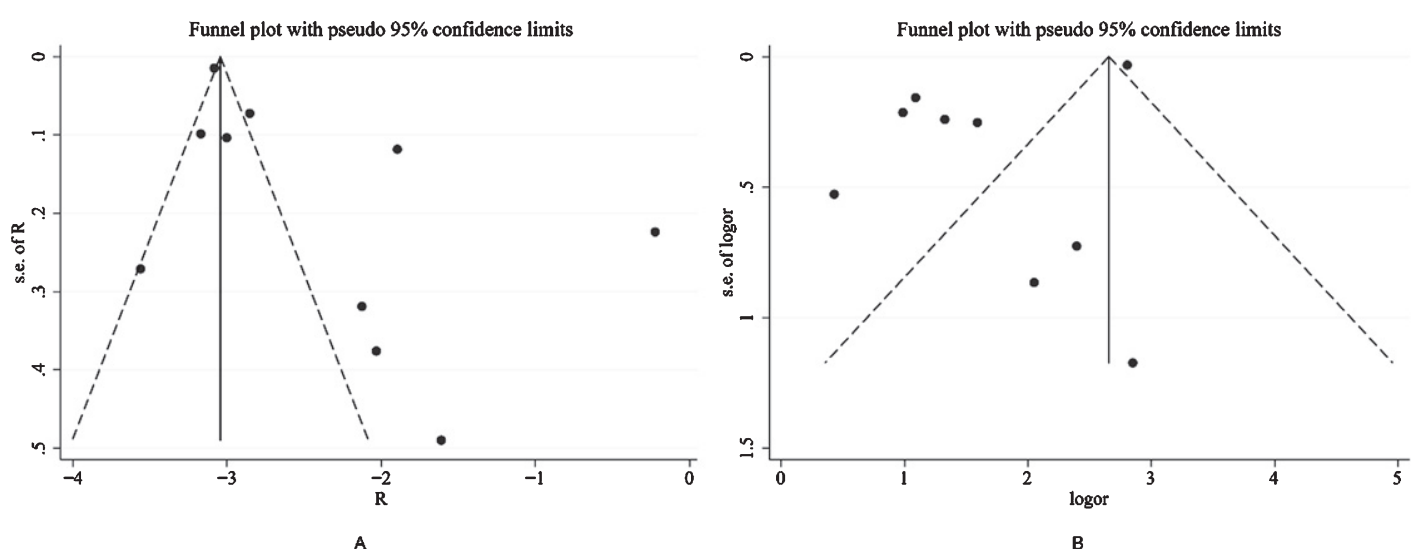

Fig. 3. Visual inspection of the funnel plot shows substantial asymmetry, suggesting that there may be potential publication bias.

among the remaining studies $\left(p=0.103, I^{2}=41.3 \%\right)$. Visual inspection of the funnel plot shows substantial asymmetry, which suggests that there may be potential publication bias (Fig. 3B).

\section{DISCUSSION}

To our knowledge, this is the first meta-analysis to show that patients with dementia may be at high risk for poor clinical outcomes from COVID-19. Our study found that $9 \%$ of patients infected with COVID19 have dementia comorbidities. Furthermore, we also found that compared with patients with no dementia, dementia patients have a higher mortality rate from COVID-19 infection. As our study suggests, people with dementia usually have multiple comorbidities in comparison with other diseases, which increases the risk of hospitalization and mortality from viral and bacterial infections. Patients with dementia need to maintain strict management, even those living in retirement facilities or nursing homes. Considering the vulnerability of these patients, medical support should be involved in addition to strict control. 


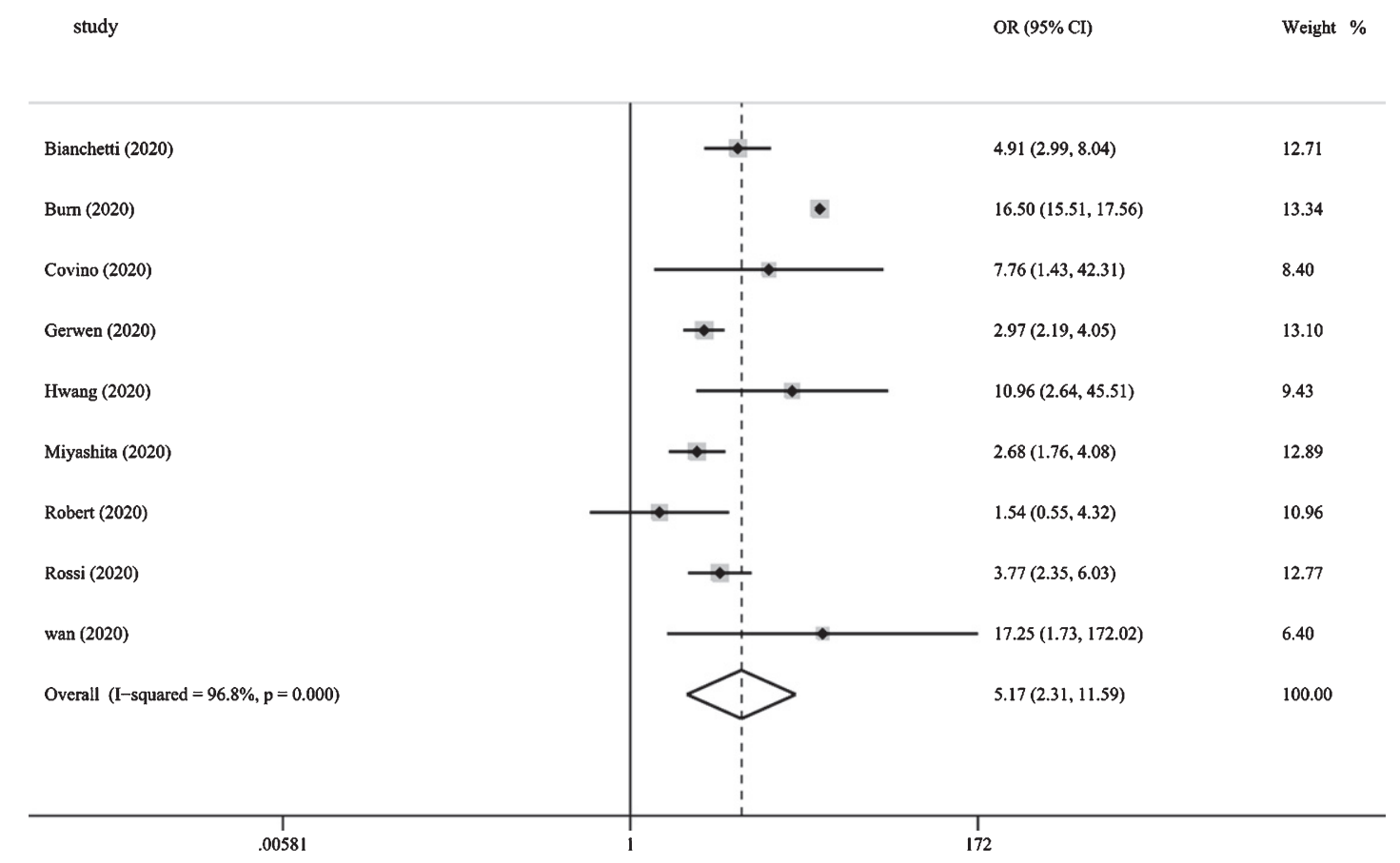

Fig. 4. Pooled results from the random-effects model for the mortality of dementia comorbidities in patients with COVID-19.

The higher incidence and mortality of COVID-19 in dementia patients can be attributed to the following aspects. First, although there are considerable uncertainties and variability in the clinical prognosis of COVID-19, age and combined underlying diseases have always been the most important risk factors for a poor prognosis [26]. Interestingly, age and comorbidities (e.g., hypertension, diabetes, and cerebrovascular disease) are also established risk factors for dementia [27]. Compared with patients with no dementia, dementia patients are more likely to suffer from diseases such as hypertension, diabetes, and pneumonia [28]. According to reports, in the absence of a pandemic, the death rate from pneumonia in dementia patients is twice as high as that of people without dementia [29]. As a result, patients with dementia usually have multiple comorbidities and are vulnerable when attacked by SARS-Cov- 2 . Human immune function is also essential to fight against COVID-19 because few studies have reported infections in children. Second, the poor outcome following SARS-CoV-2 infection is generally related to the "cytokine storm" [4]. One of the reasons that patients with dementia are at higher risk may be due to the presence of higher baseline inflammation [30]. It has been proven that the cytokine storm associated with COVID-19 is related to the increase in several proinflammatory cytokines, such as tumor necrosis factor-alpha, interleukin-1, and interleukin6 , all of which have been identified to be elevated in dementia [31]. In addition, Yamamoto et al. suggested that the poor outcome following SARS-CoV-2 infection is related to acute respiratory distress syndrome, cytokine storm, acute hypercoagulable state, and autonomic dysfunction [4]. Third, patients with dementia may be unable to follow the recommendations of public health authorities, such as covering their mouth and nose when coughing, monitoring and reporting COVID-19 symptoms, and keeping distance from others to reduce the spread of COVID19 [32]. Patients with mild cognitive impairment or mild dementia may be unwilling or unable to comply due to apathy or depression. Patients with severe dementia are not able to understand or remember most of the recommendations due to the severity of their short-term memory loss and overall cognitive impairment. Forth, a cohort study showed that the APOE4 allele increased the risk of severe COVID-19 infection, which may partly explain the high prevalence of COVID-19 in individuals with dementia [33-35]. Finally, there are numerous reports as to why long-term care patients are particularly susceptible to COVID-19, with close cohabitation being a major factor [36]. Recent Canadian data show that 
the mortality rate among nursing home residents is as high as $26 \%$ [10]. Many nursing home residents have dementia, associated with impairments in memory, language, insight, and judgment that impact their ability to understand and appreciate the necessity of isolation and to voluntarily comply with isolation procedures. It is challenging to achieve effective isolation for patients with dementia, which increases the risk of COVID-19 infection.

Significant heterogeneity was found in this study. Through a sensitivity analysis, we found that Burn et al. contributed to the heterogeneity. Excluding this study reduced the overall risk estimate, but slight heterogeneity was observed in the remaining studies. The larger sample size may partially explain this heterogeneity. However, apart from that, we could not determine a reasonable explanation.

This meta-analysis has several limitations. First, caution should be exercised when interpreting the overall estimates due to the significant heterogeneity. We could not determine a reasonable explanation for this heterogeneity. However, although the unexplained significant heterogeneity may limit the interpretation of the pooled estimates, our metaanalysis still provides reliable evidence for uncertain factors. Second, the potential confusion of other risk factors (such as age, gender, vascular disease, and diabetes) cannot be ruled out, which may aggravate the vulnerability of patients with dementia and COVID-19 at the same time. Third, we only searched the English databases, which may partly explain the significant publication bias. The significant heterogeneity across studies may also be one of the reasons for publication bias.

\section{Conclusions}

In conclusion, this meta-analysis provides evidence that individuals with dementia are not only prone to develop COVID-19 but also show unfavorable outcomes. In addition to warning dementia patients and their caregivers to stay isolated during the epidemic, the actions of medical staff and decision makers should be focused on this vulnerable group.

\section{ACKNOWLEDGMENTS}

We would like to thank all the authors who contributed to the systematic review.

This work was supported by the China National Science and Technology Major Project for "Essential new drug research and development" (No.2018ZX
09301038-003). The funding source had no role in the study.

Authors' disclosures available online (https:// www.j-alz.com/manuscript-disclosures/20-1016r1).

\section{REFERENCES}

[1] Zhou F, Yu T, Du R, Fan G, Liu Y, Liu Z, Xiang J, Wang Y, Song B, Gu X, Guan L, Wei Y, Li H, Wu X, Xu J, Tu S, Zhang Y, Chen H, Cao B (2020) Clinical course and risk factors for mortality of adult inpatients with COVID-19 in Wuhan, China: a retrospective cohort study. Lancet 395, 1054-1062.

[2] WHO Coronavirus Disease Dashboard (2020) https://www. who.int/emergencies/diseases/novel-coronavirus-2019.

[3] Huang C, Wang Y, Li X, Ren L, Zhao J, Hu Y, Zhang L, Fan G, Xu J, Gu X, Cheng Z, Yu T, Xia J, Wei Y, Wu W, Xie X, Yin W, Li H, Liu M, Xiao Y, Gao H, Guo L, Xie J, Wang G, Jiang R, Gao Z, Jin Q, Wang J, Cao B (2020) Clinical features of patients infected with 2019 novel coronavirus in Wuhan, China. Lancet 395, 497-506.

[4] Yamamoto V, Bolanos JF, Fiallos J, Strand SE, Morris K, Shahrokhinia S, Cushing TR, Hopp L, Tiwari A, Hariri R, Sokolov R, Wheeler C, Kaushik A, Elsayegh A, Eliashiv D, Hedrick R, Jafari B, Johnson JP, Khorsandi M, Gonzalez N, Balakhani G, Lahiri S, Ghavidel K, Amaya M, Kloor H, Hussain N, Huang E, Cormier J, Wesson AJ, Wang JC, Yaghobian S, Khorrami P, Shamloo B, Moon C, Shadi P, Kateb B (2020) COVID-19: Review of a 21st century pandemic from etiology to neuro-psychiatric implications. $J$ Alzheimers Dis 77, 459-504.

[5] (2019) Alzheimer's Association Report: 2019 Alzheimer's disease facts and figures. Alzheimers Dement 3, 321-387.

[6] Rogers NT, Steptoe A, Cadar D (2017) Frailty is an independent predictor of incident dementia: Evidence from the English Longitudinal Study of Ageing. Sci Rep 1, 15746.

[7] Nikolich-Zugich J, Knox KS, Rios CT, Natt B, Bhattacharya D, Fain MJ (2020) SARS-CoV-2 and COVID-19 in older adults: what we may expect regarding pathogenesis, immune responses, and outcomes. Geroscience 2, 505-514.

[8] Azarpazhooh MR, Amiri A, Morovatdar N, Steinwender S, Rezaei Ardani A, Yassi N, Biller J, Stranges S, Tokazebani Belasi M, Neya SK, Khorram B, Sheikh Andalibi MS, Arsang-Jang S, Mokhber N, Di Napoli M (2020) Correlations between COVID-19 and burden of dementia: An ecological study and review of literature. J Neurol Sci 416, 117013.

[9] Killen A, Olsen K, Mckeith IG, Thomas AJ, O'Brien JT, Donaghy P, Taylor J (2020) The challenges of COVID19 for people with dementia with Lewy bodies and family caregivers. Int J Geriatr Psychiatry 10, 1002/gps.5393.

[10] Iaboni A, Cockburn A, Marcil M, Rodrigues K, Marshall C, Garcia MA, Quirt H, Reynolds KB, Keren R, Flint AJ (2020) Achieving safe, effective, and compassionate quarantine or isolation of older adults with dementia in nursing homes. Am J Geriatr Psychiatry 28, 835-838.

[11] Greenberg NE, Wallick A, Brown LM (2020) Impact of COVID-19 pandemic restrictions on community-dwelling caregivers and persons with dementia. Psychol Trauma 12, S220-S221.

[12] Vaitheswaran S, Lakshminarayanan M, Ramanujam V, Sargunan S, Venkatesan S (2020) Experiences and needs of caregivers of persons with dementia in india during the 
COVID-19 pandemic-a qualitative study. Am J Geriatr Psychiatry 20, S1064-7481.

[13] Bianchetti A, Rozzini R, Guerini F, Boffelli S, Ranieri P, Minelli G, Bianchetti L, Trabucchi M (2020) Clinical presentation of COVID19 in dementia patients. $J$ Nutr Health Aging 24, 560-562.

[14] Atkins JL, Masoli JAH, Delgado J, Pilling LC, Kuo C, Kuchel GA, Melzer D (2020) Preexisting comorbidities predicting COVID-19 and mortality in the UK Biobank Community Cohort. J Gerontol A Biol Sci Med Sci 75, 2224-2230.

[15] Wan Y, Wu J, Ni L, Luo Q, Yuan C, Fan F, Liu H, Zhang C, Xiang Y, Xie Q (2020) Prognosis analysis of patients with mental disorders with COVID-19: a single-center retrospective study. Aging 12, 11238-11244.

[16] Moher D, Liberati A, Tetzlaff J, Altman DG; PRISMA Group (2009) Preferred reporting items for systematic reviews and meta-analyses: the PRISMA statement. $B M J$ 62, b2535.

[17] Stang A (2010) Critical evaluation of the Newcastle-Ottawa scale for the assessment of the quality of nonrandomized studies in meta-analyses. Eur J Epidemiol 9, 603-605.

[18] Higgins JP, Thompson SG, Deeks JJ, Altman DG (2003) Measuring inconsistency in meta-analyses. BMJ 7414, 557-560.

[19] Miyashita S, Yamada T, Mikami T, Miyashita H, Chopra N, Rizk D (2020) Impact of dementia on clinical outcomes in elderly patients with coronavirus 2019 (COVID-19): an experience in New York. Geriatr Gerontol Int 7, 732-734.

[20] De Smet R, Mellaerts B, Vandewinckele H, Lybeert P, Frans E, Ombelet S, Lemahieu W, Symons R, Ho E, Frans J, Smismans A, Laurent MR (2020) Frailty and mortality in hospitalized older adults with COVID-19: retrospective observational study. J Am Med Dir Assoc 7, 928-932.

[21] Covino M, De Matteis G, Santoro M, Sabia L, Simeoni B, Candelli M, Ojetti V, Franceschi F (2020) Clinical characteristics and prognostic factors in COVID-19 patients aged $\geq 80$ years. Geriatr Gerontol Int 7, 704-708.

[22] van Gerwen M, Alsen M, Little C, Barlow J, Genden E, Naymagon L, Tremblay D (2020) Risk factors and outcomes of COVID-19 in New York City; a retrospective cohort study. J Med Virol, doi: 10.1002/jmv.26337.

[23] Hwang J, Kim J, Park J, Chang MC, Park D (2020) Neurological diseases as mortality predictive factors for patients with COVID-19: a retrospective cohort study. Neurol Sci $\mathbf{9}$, 2317-2324.

[24] Burn E, Tebé C, Fernandez-Bertolin S, Aragon M, Recalde M, Roel E, Prats-Uribe A, Prieto-Alhambra D, DuarteSalles T (2020) The natural history of symptomatic COVID-19 in Catalonia, Spain: a multi-state model including 109,367 outpatient diagnoses, 18,019 hospitalisations, and 5,585 COVID-19 deaths among 5,627,520 people. medRxiv https://doi.org/10.1101/2020.07.13.20152454.
[25] Rossi PG, Marino M, Formisano D, Venturelli F, Vicentini M, Emilia R (2020) COVID-19/SARS-CoV-2 News from Preprints; Characteristics and outcomes of a cohort of SARS-CoV-2 patients in the Province of Reggio Emilia, Italy. medRxiv, https://doi.org/10.1101/2020.04.13. 20063545.

[26] Padala SP, Jendro AM, Orr LC (2020) Facetime to reduce behavioral problems in a nursing home resident with Alzheimer's dementia during COVID-19. Psychiatry Res 88, 113028

[27] Ardura-Fabregat A, Boddeke EWGM, Boza-Serrano A, Brioschi S, Castro-Gomez S, Ceyzériat K, Dansokho C, Dierkes T, Gelders G, Heneka MT, Hoeijmakers L, Hoffmann A, Iaccarino L, Jahnert S, Kuhbandner K, Landreth G, Lonnemann N, Löschmann PA, Mcmanus RM, Paulus A, Reemst K, Sanchez-Caro JM, Tiberi A, Van der Perren A, Vautheny A, Venegas C, Webers A, Weydt P, Wijasa TS, Xiang X, Yang Y (2017) Targeting neuroinflammation to treat Alzheimer's disease. CNS Drugs 12, 1057-1082.

[28] Bauer K, Schwarzkopf L, Graessel E, Holle R (2014) A claims data-based comparison of comorbidity in individuals with and without dementia. BMC Geriatr 10, 37-45.

[29] Foley NC, Affoo RH, Martin RE (2015) A systematic review and meta-analysis examining pneumonia-associated mortality in dementia. Dement Geriatr Cogn Disord 12, 52-67.

[30] Naughton SX, Raval U, Pasinetti GM (2020) Potential novel role of COVID-19 in Alzheimer's disease and preventative mitigation strategies. J Alzheimers Dis 1, 21-25.

[31] Scarpa R, Costa L, Del PA, Caso F (2020) Role of thymopoiesis and inflamm-aging in COVID-19 phenotype. Pediatr Neonatol 3, 364-365.

[32] Brown EE, Kumar S, Rajji TK, Pollock BG, Mulsant BH (2020) Anticipating and mitigating the impact of the COVID-19 pandemic on Alzheimer's disease and related dementias. Am J Geriatr Psychiatry 7, 712-721.

[33] Kuo CL, Pilling LC, Atkins JL, Masoli J, Delgado J, Kuchel GA, Melzer D (2020) ApoE e4e4 genotype and mortality with COVID-19 in UK Biobank. J Gerontol A Biol Sci Med Sci 75, 1801-1803.

[34] Finch CE, Kulminski AM (2020) The ApoE locus and COVID-19: are we going where we have been? J Gerontol A Biol Sci Med Sci, doi: 10.1093/gerona/glaa200.

[35] Mok VCT, Pendlebury S, Wong A, Alladi S, Au L, Bath PM, Biessels GJ, Chen C, Cordonnier C, Dichgans M, Dominguez J, Gorelick PB, Kim S, Kwok T, Greenberg SM, Jia J, Kalaria R, Kivipelto M, Naegandran K, Lam LCW, Lam BYK, Lee ATC, Markus HS, O'Brien J, Pai MC, Pantoni L, Sachdev P, Skoog I, Smith EE, Srikanth V, Suh GH, Wardlaw J, Ko H, Black SE, Scheltens P (2020) Tackling challenges in care of Alzheimer's disease and other dementias amid the COVID-19 pandemic, now and in the future. Alzheimers Dement, doi: 10.1002/alz.12143. 